\title{
ДЕРЖАВНЕ РЕГУЛЮВАННЯ ТА ПЕРСПЕКТИВНІ НАПРЯМКИ РОЗВИТКУ ЕНЕРГЕТИЧНОГО КОМПЛЕКСУ В УКРАЇНІ
}

\author{
Губанова Н.Н., к.е.н., доцент, \\ Грибинюк Д.В., студентка (НТУ «ХПИ»)
}

В статті розглядаються проблеми енергетичного розвитку в Украӥни. Серед них: проблеми фінансування енергетичного сектора, недостатній рівень попиту на українські енергетичні активи $з$ боку іноземних інвесторів, нераціональне використання енергетики та негативний вплив енергетики на навколишнє середовище. Розглянуто також перспективи розвитку альтернативної енергетик в сучасної економіки Украӥни.

Ключові слова: паливно-енергетичний комплекс, науково-технічний розвиток, альтернативні джерела енерхії.

\section{ГОСУДАРСТВЕННОЕ РЕГУЛИРОВАНИЕ И ПЕРСПЕКТИВНЫЕ НАПРАВЛЕНИЯ РАЗВИТИЯ ЭНЕРГЕТИЧЕСКОГО КОМПЛЕКСА В УКРАИНЕ}

\author{
Губанова Н.Н., к.е.н., доцент, \\ Грибинюк Д.В., студентка (НТУ «ХПИ»)
}

В статье рассматриваются проблемь энергетического развития в Украине. Среди них: проблемь финансирования энергетического сектора, недостаточный уровень спроса на украинские энергетические активы со стороны иностранных инвесторов, нерачиональное использование энергетики и негативное влияние энергетики на окружаюшую среду. Рассмотрены также перспективы развития альтернативной энергетики в современной экономике Украины.

Ключевье слова: топливно-энергетический комплекс,научно-техническое развитие, альтернативные источники энергии.

\section{GOVERNMENT REGULATION AND ENERGY DEVELOPMENT PROBLEMS IN UKRAINE}

\author{
Gubanova N.N., PhD, Associate Professor, \\ Hrybyniuk D.V., a student (National Technical University "Kharkiv Polytechnic Institute")
}

Our country is highly dependent on exhaustible sources of energy (oil and gas). At the present rates of their using there are only a few decades left for doing it. That is why it makes sense to think about simultaneous solving of two problems: high levels of pollution and scarcity of widely used energy sources.

Today in many European countries and in the USA new technologies that minimize the impact on the environment and maximize energy resources efficiency are being actively introduced. Of course, such projects require high level of capital investment and though only wealthy country can implement these technologies. But development in this direction, encourage investors to invest in alternative energy sources, providing right state policy, support those companies that have already begun to move in this direction would help our country develop the energy sector in the future. It would also help our economy to exit financial and political crisis. So today the alternative energy sources implementation is one of the priority directions of research.

Keywords: fuel and energy complex, scientific and technological development, alternative energy sources.

Постановка проблеми. На сьогоднішній день головною проблемою становлення енергетичного сектору $є$ недостатнє фінансування і малий процент науково-технічного розвитку окремих ланок ПЕК, а також велика енергетична залежність від інших країн світу.

(C) Губанова Н.Н.,

Грибинюк Д.В.
Аналіз останніх досліджень і публікацій. Проблемою енергетичного розвитку в Україні займаються Святненко А, Васюкова Г.Т Бондаренко В.I. та ін. [4,8,11].

Невирішена частина загальної проблеми. Аналіз праць останнього десятиліття, присвячених проблемам розвитку паливно- 
енергетичного комплексу й забезпечення енергетичної безпеки країни свідчить, що удосконалення організаційно-економічного механізму управління ресурсним забезпеченням енергетичної безпеки України i його окремих частин $\epsilon$ одним 3 невирішених питань загальної проблеми відродження паливно-енергетичного комплексу (ПЕК) країни. Під словосполученням «відродження ПЕК» розуміється підвищення рівня розвитку ПЕК України i виведення його 3 сучасного недосконалого стану.

Мета даного дослідження - розглянути проблеми енергетичного розвитку в Україні; альтернативні джерела енергії, які найкращим чином будуть сприяти поліпшенню екологічного та економічного стану України.

Виклад основного матеріалу. Основні проблеми фінансування енергетичного сектора, в першу чергу, пов'язані 3 відсутністю в Україні джерел довгострокового банківського кредитування. У світовій практиці енергетичні компанії мають можливість залучати недорогі довгострокові кредитні ресурси для модернізації існуючих і будівництва нових потужностей, а в Україні, за винятком кількох найбільших компаній, вони такої можливості позбавлені. Існуючі тарифи, за винятком встановлених на високому рівні тарифів на відновлювану енергію, також не дозволяють виробникам акумулювати кошти для реалізації інвестиційних програм. Третім чинником $€$ недостатній рівень попиту на українські енергетичні активи з боку іноземних стратегічних інвесторів. Це викликано як високими ризиками інвестування в Україну, так і відсутністю в іноземних компаній можливостей конкурувати 3 українськими фінансово-промисловими групами, які мають більше можливостей для відстоювання своїх інтересів у цьому секторі [9]. Крім проблем фінансування енергетичного сектора, все більшу увагу привертають проблеми глобального рівня негативний вплив енергетики на навколишнє середовище.

ПЕК, енергетика, транспорт i промисловість, де переважають процеси, основою яких $\epsilon$ горіння, відомі як основні джерела антропогенного забруднення навколишнього середовища.

Однозначно говорити про негативний ефект енергетики неправильно, адже $є$ багато факторів як негативного, так і позитивного впливу ПЕК на навколишнє середовище.

Виробництво електроенергії на ТЕС супроводжується виділенням великої кількості тепла, тому такі електростанції намагаються будувати біля міст і промислових центрів для їхнього тепло - і електропостачання. Робота ТЕС заснована на використанні органічного палива (вугілля, нафти, газу, торфу, сланців). У результаті згоряння великої кількості мінерального палива відбуваються зміни навколишнього середовища (повітря, води і землі) [8].

Головні зміни у результаті діяльності TEC:

- Забруднення атмосфери газоподібними i пиловими викидами. $\mathrm{y}$ результаті роботи електростанцій на органічному паливі, а також згоряння палива в двигунах внутрішнього згоряння в атмосферу викидається вуглекислий газ, концентрація якого виростає приблизно на $0,25 \%$ за рік. У зв'язку з цим збільшення вуглекислого газу може послужити нагріванню атмосфери за рахунок парникового ефекту. Вуглекислий газ $є$ прозорим для сонячних променів, він вільно пропускає їх до поверхні Землі, але затримує теплові (інфрачервоні) промені, що випромінює нагріта Сонцем Земля. Температура атмосфери, таким чином, збільшується, і тим швидше, чим більше в ньому вміст вуглекислого газу[11].

- Викиди з труб ТЕС в атмосферу окислів сірки й азоту. Взаємодіючи $з$ атмосферною водою, ці гази утворюють сірчану й азотну кислоти. Випадання кислотних дощів вже сьогодні призводить до окислення грунтів і прісних водойм, загибелі багатьох видів фауни і флори, зниженню врожайності сільськогосподарських культур, загибелі хвойних лісів, руйнуванню архітектурних будівель і пам'ятників, і ін. Дуже небезпечними $є$ окиси азоту для людини.

- Виділення земель під кар'єри і відвали шлаку. Потреба паливно-енергетичного комплексу у великій кількості вугілля визначає масштаби видобутку цього виду сировини. Оскільки відкритий спосіб видобутку для гірників більш економний, закладаються великі кар'єри. Сотні гектарів займають відвали порожніх порід вугільних шахт, а також шлаків і попелу біля ТЕС. В Україні з їі багатими, родючими чорноземами таке виділення земель особливо шкідливе. Наприклад, в одному лише Донбасі відвали і кар'єри, що відробили, займають площу 50 тисяч гектарів. Ця площа збільшується, тому що сьогодні переробляють лише 11,5\% відвалів[11].

- Відчуження земель під лінії електропередач. Сьогодні доведено, що довгий вплив на організм людини чи тварини електромагнітних полів викликає негативні наслідки [11].

Інша ситуація 3 ГЕС - вони мають як негативні так і деякі позитивні екологічні переваги. ГЕС не забруднюють повітря шкідливими викидами i сприяють заощадженню великої кількості палива за рахунок полегшення режиму роботи ТЕС.

Головні зміни в результаті діяльності ГЕС. Найчастіше ГЕС, побудовані на рівнинних ріках і в результаті цього водоймищами Дніпровського 
каскаду ГЕС затоплено величезні площі родючих

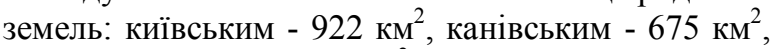

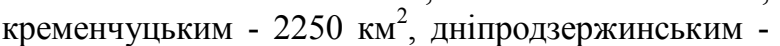
567 км$^{2}$, дніпропетровським - 410 км $^{2}$, каховським -

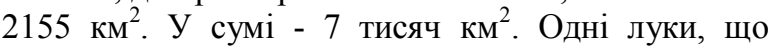
пішли під воду Київського моря, забезпечували тваринницькою продукцією й овочами половину міста Києва. 3 затоплених площ довелося виселити жителів сотень сіл, прокласти нові комунікації і дороги. Затоплено велику кількість історичних і ландшафтних пам'ятників [11].

За останнє десятиріччя, в напрямку альтернативної енергетики, Україна зробила доволі багато кроків вперед. Наукові конференції, співробітництво 3 міжнародними організаціями i багатьма високо розвиненими країнами світу поступово призвело до позитивних зрушень у розвитку альтернативної енергетики.

Для мінімізації імпорту енергоресурсів, в Україні, не дивлячись на відсутність фінансової підтримки з боку держави, продовжує розвиватися альтернативна енергетика. Відповідно до реєстру альтернативних видів палива, станом на 01.07.14 в Україні діють 104 виробника альтернативного палива, із них 56 виробників твердого палива (пелети, гранули, брикети), 46 виробників рідкого сумішевого палива, 1 виробник газового палива (біогаз полігонів твердих побутових відходів) та 1 виробник водовугільного палива [2].

Достатньо великим розміром інвестицій відмічається сонячна енергетика. Незважаючи на зменшення державної підтримки, ринок сонячної енергетики активно продовжує розвиватися. За шість місяців 2013 року в Україні були побудовані та введені в експлуатацію 12 великих об'єктів загальною потужністю 167,7 мВт. Таким чином, загальна встановлена потужність наших сонячних електростанцій в Україні збільшилася на 51,4 \%, до 494 МВт. Інвестиції в галузь сонячної енергетики в першому півріччі 2013 року склали більше ніж 360 мЛн. євро [3].

Розвиток альтернативних джерел енергії та стимулювання до здійснення заходів 3 енергоефективності у житлових будинках та в промислових об'єктах може компенсувати для домогосподарств i підприємств неминуче зростання витрат на комунальні послуги та енергоносії, внаслідок поступового приведення відповідних цін та тарифів до економічно обгрунтованого рівня. Це дозволить забезпечити доступність комунальних послуг та попередить енергетичну бідність населення України [2].

Згідно українського законодавство «Про альтернативні джерела енергії» від 20 лютого 2003 року основними засадами державної політики у сфері альтернативних джерел енергії $є$ :

- нарощування обсягів виробництва та споживання енергії, виробленої з альтернативних джерел, 3 метою економного витрачання традиційних паливно-енергетичних ресурсів та зменшення залежності України від їх імпорту шляхом реструктуризації виробництва i раціонального споживання енергії за рахунок збільшення частки енергії, виробленої 3 альтернативних джерел;

- додержання екологічної безпеки за рахунок зменшення негативного впливу на стан довкілля при створенні та експлуатації об'єктів альтернативної енергетики, а також при передачі, транспортуванні, постачанні, зберіганні та споживанні енергії, виробленої з альтернативних джерел;

- додержання безпеки для здоров'я людини на об'єктах альтернативної енергетики на всіх етапах виробництва, а також при передачі, транспортуванні, постачанні, зберіганні та споживанні енергії, виробленої 3 альтернативних джерел;

- науково-технічне забезпечення розвитку альтернативної енергетики, популяризація та впровадження науково-технічних досягнень у цій сфері, підготовка відповідних фахівців у вищих та середніх навчальних закладах;

- додержання законодавства всіма суб'єктами відносин, пов'язаних 3 виробництвом, збереженням, транспортуванням, постачанням, передачею і споживанням енергії, виробленої 3 альтернативних джерел;

- додержання умов раціонального споживання та економії енергії, виробленої 3 альтернативних джерел;

- залучення вітчизняних та іноземних інвестицій і підтримка підприємництва у сфері альтернативних джерел енергії, в тому числі шляхом розробки і здійснення загальнодержавних і місцевих програм розвитку альтернативної енергетики [1 ст. 3].

Висновки. Українська енергетика на сьогоднішній день переживає не кращі часи. Ми маємо суттєвий динамічний потенціал для залучення інвестицій i для розвитку альтернативної енергетики, але недосконале законодавство, а також економічна та політична кризи не дозволяють енергетиці розвиватися у повній мірі. Однією з найперших цілей держави повинно бути покращення інвестиційного клімату в Україні, шляхом податкової, судової і ще деяких реформ, так як альтернативна енергетика не може ефективно розвиватися без суттєвих капіталовкладень.

\section{СПИСОК ЛІТЕРАТУРИ}

1. Закон України «Про альтернативні джерела енергії».// Відомості Верховної Ради України (ВВР) - 2003, - N 24, ст.155. Із змінами, 
внесеними згідно із Законами N 601-VI ( $601-17$ ) від 25.09.2008, BBP, 2009, N 13, ст.155, N 663-VII ( 663-18 ) від 24.10.2013, ВВР, 2014, N 22, ст.781, N 1193-VII ( $1193-18$ ) від 09.04.2014, BBP, 2014, N 23, ст.873.

$$
2 .
$$

енергозабезпечення. Фокус на будівлі. [Електронний ресурс] Держенергоефективності України. - 2014. - Режим доступу:

Http://saee.gov.ua/uk/consumers/derzhpidtrymka-energozabespechenya/focus-na-budivli

3. Відновлювана енергетика. Сучасний стан [Електронний ресурс] Держенергоефективності України. - 2014. - Режим доступу:

http://saee.gov.ua/uk/activity/vidnovlyuvanaenerhetyka/suchasny-stan

4. Бондаренко В.I. Энергетика: история, настоящее и будущее. От огня и воды к электричеству / Бондаренко В.І., Варламов Г. Б., Вольчин І.А. Монографія- К., 2011. - 264 с.

5. Гайдаєнко I. Альтернативна енергетика в Україні: стан та перспективи розвитку/ Гайдаєнко I. // Наукові записки 3 української історії: Зб. наук. статей, 2014. - Вип. 34. - С. 146151.

6. Калетнік Г.М. Біопалива: ефективність їх виробництва та споживання в АПК України:
Калетнік Г.М., Пришляк В. М.; навч. посібник. К:Аграрна наука, 2010. - 327 с.

7. Ратушняк Г.С. Енергозбереження в сільсько-господарській біоконверсії / Ратушняк Г.С., Джеджула В.В.; навч. посібник. - Вінниця. ВНТУ, 2006. - $83 \mathrm{c}$.

8. Святненко А. «Отримати свою частину зеленого пирога» / Святненко А., Власов В.С.// Дзеркало тижня. - 2010. - № 47

9. Дослідження на основі опитування учасників галузевого ринку [Електронний ресурс] - KPMG - Січень 2013. - Режим доступу: http://www.kpmg.com/UA/uk/IssuesAndInsights/Artic lesPublications/Documents/KPMG_Energy_Survey_1 1012013.pdf

10. Кравченко Е. Альтернативная энергетика 2013. Нормативно-правовое регулирование [Електронний ресурс] - по материалам издания «Юридическая газета» / Е. Кравченко - 2013. - № 42. - Режим доступа: http:/gc.ua/business-news/6672/

11. Васюкова Г.Т Екологія Підручн [Електронний pecypc] http://libfree.com/175948304ekologiyaekologiya_vasyukova_gt.html

12. Тунік Є., Філатова А. Від гною i ліхтарі горять [Електронний ресурс] - Є.Тунік, А.Філатова - 2011. - Режим доступу: http://www.produced.in.ua/techno/45-vd-gnoyu-lhtargoryat.html

Рецензент д.е.н., професор НТУ «ХПI» Архієрєєв С.I. Експерт редакційної колегї к.е.н., доцент УкрДУЗТ єлагін Ю.В.

УДК 316.3 : 33 (477)

\title{
РОЛЬ СУСПІЛЬСТВА В ПРОЦЕСАХ СОЦІАЛЬНО-ЕКОНОМІЧНОЇ ТРАНСФОРМАЦІЇ УКРӒ̈НИ
}

\author{
Дикань В.В, д.е.н., доцент (УкрДУЗТ)
}

У даній статті автором обтрунтовано роль суспільства в процесах соціально-економічної трансформації України. Досліджено еволюиію поглядів на тлумачення сутності суспільства та економіки. Проаналізовано концепцію «людина - економіка», та визначено ї̈ основні положення. Запропоновано основні положення економіки для покращення рівня життя суспільства.

Ключові слова: людина, суспільство, економіка, культура, трансформація Украӥни.

\section{РОЛЬ ОБЩЕСТВА В ПРОЦЕССЕ СОЦИАЛЬНО-ЕКОНОМИЧЕСКОЙ ТРАНСФОРМАЦИИ УКРАИНЫ}

\author{
Дикань В.В., д.е.н., доцент (УкрГУЖТ)
}

В данной статье автором обоснована роль общества в процессах социально-экономической трансформащии Украины. Исследована эволющчия взглядов на толкование сущчности общества и

(C) Дикань B.B.

Вісник економіки транспорту і промисловості № 50, 2015 